\title{
STROKE ISKEMIK DENGAN MANIFESTASI DIZZINESS/VERTIGO TERISOLASI
}

\author{
ISCHEMIC STROKE PRESENTS WITH ISOLATED DIZZINESS/VERTIGO \\ Diyan Anita Sari, * Sri Sutarni, * Ismail Setyopranoto*
}

\begin{abstract}
Dizziness/vertigo, unstable walking or loss of balance are symptoms in about 50\% of stroke cases. However, only about $20 \%$ are accompanied by focal neurological signs. In the last decade, there is increasing evidence that vertigo can be the only ischemic symptom of posterior circulation stroke without a focal sign. The purpose of this systematic review is to examine the literature on ischemic stroke with the manifestation of isolated dizziness/vertigo. The literature search is done through several electronic database (Pubmed, Ebscohost, and Proquest) from 2000 to 2017 using keywords; isolated vertigo, isolated dizziness, ischemic stroke, vertebrobasilar, posterior stroke, magnetic resonance imaging (MRI). Six articles were obtained that meet the criteria. Approximately 9-10\% of patients with isolated dizziness/vertigo who had a history of vascular risk factors, found to have infarct lesions from MRI diffusion weighted imaging (DWI) examination. In this case, the territory of posterior inferior cerebellar artery (PICA) is most often involved. Acute ischemic stroke can not be excluded only on the basis of negative DWI examination results. Head impulse, nystagmus, and test of skew (HINTS) plus examination may identify acute vestibular syndrome with a central cause with better accuracy than MRI DWI at the onset of symptom.
\end{abstract}

Keywords: Acute vestibular syndrome, ischemic stroke, isolated dizziness, isolated vertigo, posterior circulation stroke

\begin{abstract}
ABSTRAK
Dizziness/vertigo, berjalan tidak stabil atau kehilangan keseimbangan merupakan gejala pada sekitar 50\% kasus stroke. Namun, hanya sekitar $20 \%$ disertai tanda neurologis fokal. Pada dekade terakhir, semakin banyak bukti bahwa vertigo dapat sebagai satu-satunya gejala iskemik sirkulasi posterior tanpa tanda fokal. Tujuan penulisan tinjauan sistematik ini adalah untuk mengkaji literatur tentang stroke iskemik dengan manifestasi hanya dizziness/vertigo terisolasi. Pencarian literatur dilakukan melalui database elektronik (Pubmed, Ebscohost, dan Proquest) dari tahun 2000 hingga 2017 dengan kata kunci; isolated vertigo, isolated dizziness, ischemic stroke, vertebrobasilar, posterior stroke, magnetic resonance imaging (MRI). Didapatkan 6 artikel yang memenuhi kriteria. Sebanyak 9-10\% dari pasien dengan dizziness/ vertigo terisolasi yang memiliki riwayat faktor risiko vaskular, ditemukan lesi infark dari pemeriksaan MRI diffusion weighted imaging (DWI). Dalam hal ini, teritori posterior inferior cerebellar artery (PICA) yang paling sering terlibat. Stroke iskemik akut tidak dapat disingkirkan hanya berdasar hasil pemeriksaan DWI negatif. Pemeriksaan head impulse, nystagmus, and test of skew (HINTS) plus dapat mengidentifikasi sindrom vestibular akut dengan penyebab sentral dengan akurasi yang lebih baik dibanding MRI DWI di awal onset gejala.
\end{abstract}

Kata kunci: Dizziness terisolasi, sindrom vestibular akut, stroke iskemik, stroke sirkulasi posterior, vertigo terisolasi *Departemen Neurologi FK, Kesehatan Masyarakat, dan Keperawatan Universitas Gajah Mada/KSM Saraf RSUP Dr. Sardjito, Yogyakarta. Korespondensi: anitasari.diyan@gmail.com.

\section{PENDAHULUAN}

Pusing merupakan istilah yang sering digunakan pasien untuk menggambarkan sensasi kepala melayang, tidak seimbang, ilusi gerak atau juga disorientasi. ${ }^{1}$ Vertigo adalah sensasi gerakan tubuh ketika tubuh tidak sedang bergerak, yang tidak sesuai dengan gerakan kepala yang normal, sedangkan dizziness adalah sensasi gangguan orientasi ruang tanpa gangguan sensasigerakan. ${ }^{2}$ Dizziness/vertigo, berjalan tidak stabil atau kehilangan keseimbangan merupakan gejala pada sekitar 50\% kasus stroke. Dizziness/ vertigo akibat penyakit serebrovaskular biasanya dikaitkan dengan tanda neurologis lain. Terkadang stroke serebelum atau batang otak mempunyai gejala vertigo yang menyerupai vestibulopati akut sehingga menyebabkan keterlambatan diagnosis stroke. ${ }^{3}$ Vertigo dapat sebagai satu-satunya gejala iskemik sirkulasi posterior tanpa tanda fokal. Mortalitas akibat kesalahan diagnosis stroke iskemik posterior cukup tinggi dan sebagian besar pasien yang bertahan hidup akan mengalami defisit neurologis menetap. ${ }^{4}$

Tujuan penulisan tinjauan sistematik ini adalah untuk mengetahui prevalensi, profil klinis stroke iskemik dengan gejala dizziness/vertigo terisolasi 
(tanpa defisit neurologis fokal lain), serta struktur anatomis yang terlibat melalui pemeriksaan magnetic resonance imaging diffusion weighted imaging (MRI DWI).

\section{PEMBAHASAN}

Pencarian literatur dilakukan melalui database elektronik Pubmed, Ebscohost, dan Proquest dari tahun 2000 hingga 2017 dengan kata kunci; ischemic stroke, posterior stroke, isolated vertigo, isolated dizziness, vertebrobasilar, MRI dan diterbitkan dalam bahasa Inggris. Penelitian dilakukan pada pasien stroke iskemik dewasa dengan manifestasi dizziness/ vertigo terisolasi atau sindrom vestibular akut, dilakukan pemeriksaan MRI pada subjek penelitian. Penilaian artikel menggunakan Joanna Briggs Institute (JBI) critical appraisal checklist untuk studi dengan desain potong lintang analitik.

Gambar 1 menunjukkan diagram PRISMA flow untuk proses seleksi dan inklusi artikel. Dari strategi pencarian melalui database elektronik diperoleh 170 artikel dari database terpilih (PubMed 92, Ebscohost 18, ProQuest 60), tiga diantaranya didapatkan duplikasi sehingga 167 artikel yang tersisa dievaluasi relevansinya melalui kajian judul dan abstrak.
Sebanyak 28 artikel disingkirkan oleh karena bukan merupakan studi pada manusia atau tidak tersedia naskah lengkap. Beberapa laporan penelitian yang tidak sesuai dengan tujuan penelitian dieksklusi, yaitu sebanyak 128 artikel. Sehingga didapatkan 11 artikel yang tersisa, 5 penelitian tidak dilakukan pemeriksaan MRI sehingga disingkirkan. Didapatkan 6 artikel yang memenuhi kriteria.

Berdasarkan dari seleksi tersebut didapatkan 6 jurnal yang akan dilakukan tinjauan sistematik, yaitu cerebellar stroke presenting with isolated dizziness: brain MRI in 136 patients, yang dipublikasikan di American Journal of Emergency Medicine; ${ }^{5}$ how commonly is stroke found in patients with isolated vertigo or dizziness attack? yang dipublikasikan di Journal of Stroke and Cerebrovascular Diseases; ${ }^{6}$ dorsal medullary infarction. distinct syndrome of isolated central vestibulopathy, yang dipublikasikan di Stroke; $;^{7}$ isolated vertigo and possibility of brain ischemia, yang dipublikasikan di Arch Iran Med ${ }^{8}$ isolated labyrinthine infarction as a harbinger of anterior inferior cerebellar artery territory infarction with normal diffusion-weighted brain MRI, yang dipublikasikan di Journal of the Neurological Sciences: ${ }^{9}$

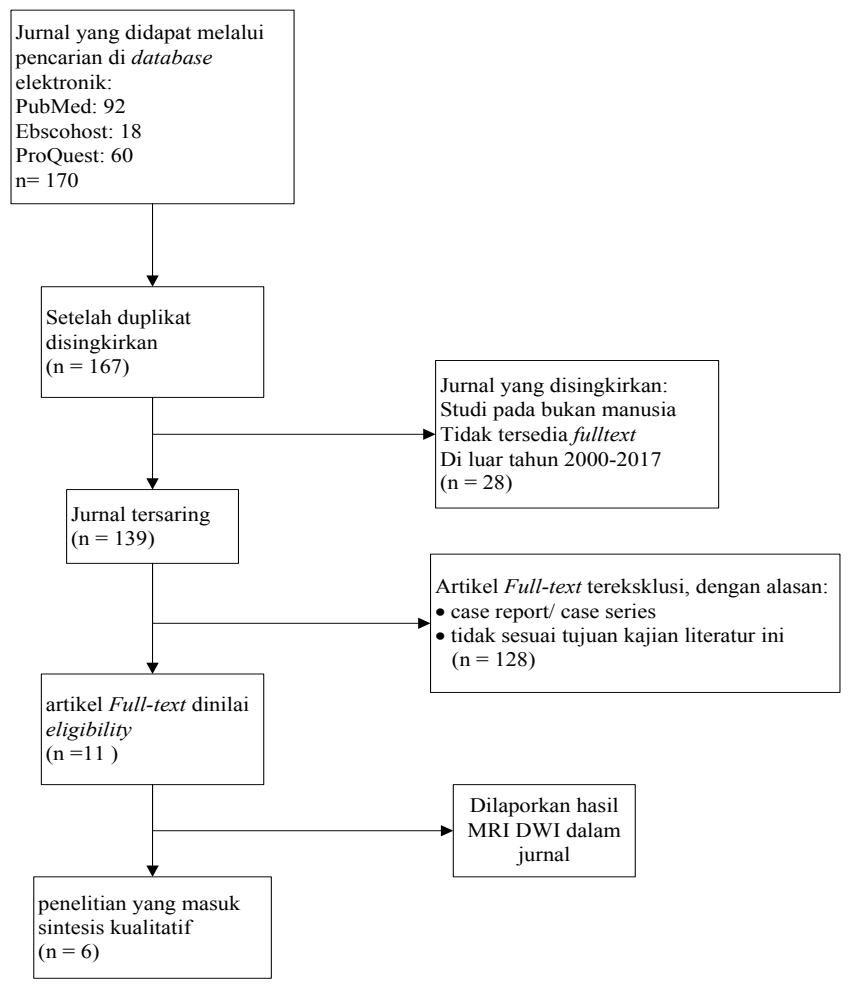

Gambar 1. Diagram PRISMA Flow untuk Proses Seleksi dan Inklusi Artikel 
Tabel 1. Karakteristik dan Metode Penelitian

\begin{tabular}{|c|c|c|c|c|c|c|}
\hline No & Peneliti & Tujuan & Desain & Inklusi & Eksklusi & MRI \\
\hline 1 & $\begin{array}{l}\text { Perloff } \\
\mathrm{dkk}, 2017\end{array}$ & $\begin{array}{l}\text { Mengetahui angka } \\
\text { kejadian stroke serebelum } \\
\text { pada pasien dizziness } \\
\text { terisolasi di UGD }\end{array}$ & Retrosprektif & $\begin{array}{l}\text { Dizziness/ } \\
\text { vertigo terisolasi } \\
\text { (nistagmus, } \\
\text { tinitus) }\end{array}$ & & $\begin{array}{l}\text { Dalam } 48 \text { jam } \\
\text { setelah admisi }\end{array}$ \\
\hline 2 & $\begin{array}{l}\text { Doijiri dkk, } \\
2016\end{array}$ & $\begin{array}{l}\text { Mengetahui frekuensi } \\
\text { stroke pada pasien dengan } \\
\text { isolated dizziness/vertigo } \\
\text { attack }\end{array}$ & Retrosprektif & $\begin{array}{l}\text { Dizziness/ } \\
\text { vertigo terisolasi } \\
\text { (nistagmus, } \\
\text { tinitus) }\end{array}$ & & $\begin{array}{l}1 \text { hari setelah } \\
\text { admisi }\end{array}$ \\
\hline 3 & $\begin{array}{l}\text { Mosarrezai } \\
\mathrm{dkk}, 2012\end{array}$ & $\begin{array}{l}\text { Untuk melakukan } \\
\text { MRI DWI pada pasien } \\
\text { isolated vertigo dengan } \\
\text { probabilitas tinggi } \\
\text { mengalami infark } \\
\text { serebri. Menganalisis } \\
\text { hubungan faktor risiko } \\
\text { kardiovaskular dengan } \\
\text { infark yang diidentifikassi } \\
\text { menggunakan DWI }\end{array}$ & Potong lintang & $\begin{array}{l}\text { Vertigo akut } \\
\text { terisolasi, }>1 \\
\text { faktor risiko }\end{array}$ & $\begin{array}{l}\text { Onset }>2 \\
\text { minggu, } \\
\text { kontraindikasi } \\
\text { MRI }\end{array}$ & $\begin{array}{l}\text { Dalam } 3 \text { hari } \\
\text { onset }\end{array}$ \\
\hline 4 & $\begin{array}{l}\text { Lee dkk, } \\
2015\end{array}$ & $\begin{array}{l}\text { Untuk mengetahui } \\
\text { gambaran klinis khusus } \\
\text { infark medula dorsal }\end{array}$ & Retrosprektif & $\begin{array}{l}\text { Infark medula } \\
\text { dorsal terisolasi }\end{array}$ & & $\begin{array}{l}0-10 \text { hari } \\
\text { onset gejala }\end{array}$ \\
\hline 5 & $\begin{array}{l}\text { Kim dkk, } \\
2009\end{array}$ & $\begin{array}{l}\text { Mengetahui frekuensi } \\
\text { infark labirintin sebagai } \\
\text { manifestasi awal infark } \\
\text { teritori AICA }\end{array}$ & Retrosprektif & $\begin{array}{l}\text { Infark area } \\
\text { AICA }\end{array}$ & & $\begin{array}{l}\text { Periode akut } \\
\&<4 \text { hari } \\
\text { pasca-MRI } \\
\text { awal }\end{array}$ \\
\hline 6 & $\begin{array}{l}\text { Lee dkk, } \\
2006\end{array}$ & $\begin{array}{l}\text { Mengetahui frekuensi } \\
\text { infark cerebellar yang } \\
\text { menyerupai neuritis } \\
\text { vestibular, pola klinis, } \\
\text { serta teritori infark yang } \\
\text { menyerupai neuritis } \\
\text { vestibular }\end{array}$ & Retrosprektif & $\begin{array}{l}\text { Infark serebelum } \\
\text { terisolasi }\end{array}$ & & $\begin{array}{l}0-4 \text { hari onset } \\
\text { gejala }\end{array}$ \\
\hline
\end{tabular}

dan cerebellar infarction presenting isolated vertigo, yang dipublikasikan di Neurology (Tabel 1). ${ }^{10}$

\section{Frekuensi Stroke Infark dengan Manifestasi Klinis Dizziness/Vertigo Terisolasi}

Dua penelitian ditemukan bahwa frekuensi stroke infark pada pasien dengan isolated dizziness/ vertigo sebesar $9,1 \%$ dan $9,5 \% ;{ }^{6,8}$ serta stroke perdarahan ditemukan pada $1,8 \%{ }^{7}$ Satu studi dilaporkan bahwa 3,7\% dari pasien dengan dizziness/vertigo terisolasi mengalami infark di area serebelum. ${ }^{5}$ Dilaporkan juga bahwa 7,4\% pasien dengan infark teritori AICA mengeluhkan vertigo dan gangguan pendengaran yang menyerupai labirintitis akut, dan akhirnya muncul gejala neurologis fokal lain. ${ }^{9}$ Satu studi lainnya ditemukan bahwa 10,4\% pasien dengan isolated cerebellar infarction memiliki gambaran klinis menyerupai neuritis vestibular (pseudo vestibullar neuritis). ${ }^{10}$ Ditemukan juga bahwa semua pasien dengan infark medula dorsal terisolasi menunjukkan klinis sindrom vestibular akut terisolasi dengan dizziness/vertigo dan ketidakseimbangan, yaitu 39\% pasien menunjukkan hasil MRI DWI awal normal atau tidak didapatkan lesi infark. Didapatkan progresi defisit neurologis fokal dikemudian hari pada $67 \%$ pasien (Tabel 2). ${ }^{7}$

\section{Aspek Anatomi}

Stroke infark dengan manifestasi dizziness/ vertigo terisolasi paling sering di serebelum, yaitu $88 \%$ ( $76 \%$ di area posterior inferior cerebellar artery/ PICA, $12 \%$ di area superior cerebellar artery /SCA) atau sekitar $10 \%$ dari seluruh pasien dengan keluhan dizziness/vertigo terisolasi, diikuti pons, medula 
Tabel 2. Hasil Penelitian

\begin{tabular}{|c|c|c|c|c|}
\hline No & Peneliti & $\begin{array}{c}\text { Frekuensi Stroke Infark } \\
\text { dengan Dizziness/Vertigo } \\
\text { Terisolasi }\end{array}$ & Lokasi Infark & Klinis \\
\hline 1 & Perloff dkk, 2017 & $3,7 \%(5 / 136$ pasien $)$ & $\begin{array}{l}\text { Teritori PICA } \\
\text { cabang medial }\end{array}$ & $\begin{array}{l}60 \% \text { gangguan gait, } 40 \% \text { nyeri } \\
\text { kepala, } 40 \% \text { tinitus }\end{array}$ \\
\hline 2 & Doijiri dkk, 2016 & $\begin{array}{l}11,3 \%(25 / 221 \text { pasien }) \\
9,5 \%(21 / 221) \text { stroke infark; } \\
1,8 \%(4 / 221) \text { stroke perdarahan }\end{array}$ & $\begin{array}{l}88 \% \text { serebelum } \\
(76 \% \text { PICA, } 12 \% \\
\text { SCA), }\end{array}$ & $\begin{array}{l}\text { Dizziness lebih banyak daripada } \\
\text { vertigo }(18 \% \text { vs } 5 \%)\end{array}$ \\
\hline 3 & Mosarrezai dkk, 2012 & $9,1 \%(5 / 55$ pasien $)$ & Tidak disebutkan & Tidak disebutkan \\
\hline \multirow[t]{2}{*}{4} & Lee dkk, 2015 & $\begin{array}{l}172 \text { stroke medula, } 18 \text { pasien } \\
\text { stroke medula dorsal terisolasi, } \\
\text { dan semuanya SVA }\end{array}$ & $\begin{array}{l}\text { Nukleus } \\
\text { vestibularis, } \\
\text { nukleus prepositus } \\
\text { hipoglosus, } \\
\text { pedunkulus } \\
\text { serebeli inferior }\end{array}$ & $\begin{array}{l}16,7 \% \text { tinnitus; } 66,7 \% \text { muncul } \\
\text { defisit neurologis fokal dalam } \\
6 \text { hari. }\end{array}$ \\
\hline & & & & $\begin{array}{l}\text { Lebih dari separuh kombinasi } \\
\text { vestibulopati sentral dan perifer }\end{array}$ \\
\hline 5 & Kim dkk, 2009 & $\begin{array}{l}\text { 7,4\% ( } 4 / 54 \text { pasien) stroke } \\
\text { AICA, dengan gambaran } \\
\text { klinis infark labirin (pseudo } \\
\text { labirintitis) }\end{array}$ & & $\begin{array}{l}\text { SNHL, paresis kanal, sebagian } \\
\text { besar nistagmus adalah GEN } \\
\text { bidireksional. Defisit fokal } \\
\text { muncul kemudian }\end{array}$ \\
\hline \multirow[t]{2}{*}{6} & Lee dkk, 2006 & $\begin{array}{l}10,4 \% \text { ( } 25 / 240 \text { pasien }) \text { stroke } \\
\text { serebelum terisolasi dengan } \\
\text { pseudo neuritis vestibular }\end{array}$ & $\begin{array}{l}\text { Teritori PICA } \\
\text { cabang medial } \\
(96 \%)\end{array}$ & $\begin{array}{l}\text { Head thrust semua normal, } \\
62,5 \% \text { nistagmus spontan, } 54 \% \\
\text { direction-changing GEN, jatuh } \\
\text { ke sisi lesi } 71 \%\end{array}$ \\
\hline & & & $\begin{array}{l}\text { AICA 4\% } \\
\text { (pedunkulus } \\
\text { serebeli media, } \\
\text { dorsolateral pons) }\end{array}$ & \\
\hline
\end{tabular}

PICA: posterior inferior cerebellar artery; SCA: superior cerebellar artery; SVA: sindrom vestibular akut; AICA: anterior inferior cerebellar artery; SNHL: sensorineural hearing loss; GEN: gaze-evoked nystagmus.

oblongata, dan korona radiata masing-masing $4 \%{ }^{6}$ Peneliti lain melaporkan bahwa 3,7\% pasien dengan keluhan dizziness/vertigo terisolasi mengalami infark di serebelum, terutama teritori PICA cabang medial. ${ }^{5}$

Penelitian pada isolated cerebellar infarction dengan klinis pseudo neuritis vestibular ditemukan bahwa lokasi yang paling sering terlibat yaitu teritori PICA cabang medial (96\%), diikuti AICA (4\%), keterlibatan area PICA ini sebagian besar unilateral. Tidak satupun pasien dengan infark teritori arteri serebelar superior menunjukkan klinis pseudo neuritis vestibular. ${ }^{10}$ Teritori AICA yang paling sering terlibat yaitu pedunkulus serebeli media dan dorsolateral pons. ${ }^{9}$ Penelitian pada pasien infark medula dorsal terisolasi ditemukan melalui MRI DWI dengan struktur anatomi yang terlibat, yaitu nukleus vestibularis, nukleus prepositus hipoglosus, dan pedunkulus serebeli inferior. ${ }^{7}$
Berdasarkan 6 jurnal penelitian yang telah dibahas sebelumnya dapat diketahui bahwa lokasi stroke paling sering mempunyai manifestasi klinis dizziness/vertigo terisolasi adalah teritori PICA, diikuti teritori AICA, yaitu serebelum teritori PICA, pons dorsolateral, pedunkulus serebeli media, pedunkulus serebeli inferior, dan medula lateral.

Infark sirkulasi posterior terbanyak pada area PICA dan SCA dibanding AICA. Pasien dengan infark serebelum biasanya memiliki gambaran klinis vertigo, mual dan muntah, nistagmus horizontal, limb ataxia, jalan tidak seimbang, serta nyeri kepala, dapat di sisi oksipital, frontal, atau regio servikal atas. Seringkali gambaran klinis infark arteri serebelum muncul akibat infark pada lateral medula atau pons, dan tidak melibatkan serebelum. Klinis tersebut meliputi defisit sensoris trigeminal dan spinotalamikus, sindrom Horner, dan lain sebagainya. Gangguan pendengaran 
unilateral dapat diakibatkan infark arteri labirintin yang merupakan cabang AICA. Perlu diingat bahwa infark medula lateral atau pons lateral dapat menyebabkan ataksia karena melibatkan pedunkulus serebeli, sementara serebelum sendiri tidak terlibat. ${ }^{11}$ Infark yang hanya melibatkan serebelum, tanpa batang otak lateral biasanya lebih sering pada infark SCA dibanding PICA atau AICA, sehingga infark yang mengakibatkan ataksia unilateral tanpa tanda batang otak lebih sering pada stroke teritori SCA, dan kondisi yang sebaliknya (tanda batang otak tanpa disertai ataksia unilateral) lebih sering akibat stroke teritori PICA atau AICA. ${ }^{11}$

Berdasarkan laporan beberapa penelitian, sindrom vestibular terisolasi dapat terjadi karena keterlibatan struktur anatomi tertentu, yaitu nukleus vestibularis, root entry zone saraf kranialis VIII di perbatasan pontomedula, medula rostral dorsolateral atau caudolateral, pons paramedian atau tegmentum mesensefalon, dan pedunkulus serebeli inferior. Selain itu, vertigo terisolasi dengan nistagmus spontan juga dapat muncul akibat infark di hemisfer serebri korteks vestibular, tetapi sangat jarang. ${ }^{12}$

\section{Medula oblongata}

Infark medula dibagi menjadi lateral dan medial. Infark medula lateral merupakan prototipe sindrom vestibular sentral karena melibatkan nukleus vestibular. Infark medula dorsolateral (sindrom Wallenberg) melibatkan nukleus vestibular inferior dan medial dan didapatkan gejala mual, muntah, dizziness/vertigo, dan ketidakseimbangan. Tanda klinis lain yang ditemui pada infark medula lateral meliputi sindrom Horner, gangguan sensasi nyeri dan suhu pada wajah sisi ipsilateral dan badan dan anggota gerak kontralateral lesi, disfagia, ataksia, dan suara parau. ${ }^{12}$ Sebagian besar pasien dengan infark nukleus vestibular terisolasi menunjukkan tanda klinis vestibulopati perifer dan sentral, yang meliputi nistagmus spontan kontralateral lesi, direction-changing gaze-evoked nystagmus (GEN), head impulse test (HIT) positif ke sisi lesi atau kedua arah, serta paresis kalori ipsilateral lesi. ${ }^{12}$

Vestibulopati sentral terisolasi dapat diakibatkan lesi pada struktur vestibular di medula dorsal, yaitu nukleus vestibularis, nukleus prepositus hipoglosi, dan pedunkulus serebeli inferior. Nukleus vestibularis merupakan yang pertama menerima sinyal vestibular perifer, tetapi juga terlibat dalam modulasi dan integrasi sentral sinyal tersebut sehingga lesi yang melibatkan nukleus vestibularis menghasilkan gambaran klinis kombinasi disfungsi vestibular perifer dan sentral, yaitu spontaneous nystagmus (SN) horizontal torsional dengan fase cepat ke sisi sehat, HIT positif ipsilesi, parese kalori ipsilesi, respons vestibular evoked myogenic potential (VEMP) menurun atau hilang dengan stimulasi telinga ipsilesi, di mana semua tanda tersebut sesuai dengan vestibulopati perifer unilateral, disertai tanda vestibulopati sentral, yaitu direction-changing GEN, HIT kontralesi normal atau terganggu. ${ }^{7}$

Nukleus prepositus hipoglosi (NPH) terletak di rostral medula dan kaudal pons di antara nukleus hipoglosus dan abdusen. NPH berperan dalam integrasi neural untuk gerak mata horizontal. NPH biasanya divaskularisasi arteri yang juga mensuplai fasikulus longitudinalis medial dan nukleus abdusen, sehingga lesi NPH sering disertai kelemahan horizontal gaze dan parese wajah tipe perifer. Peneliti lain melaporkan pada kasus lesi NPH dengan gambaran klinis sindrom vestibular akut (SVA) tanpa defisit neurologis lain. NPH menerima sinyal vestibular kanalis semisirkularis. Oliva inferior menerima proyeksi inhibisi dari NPH bilateral. Proyeksi ini lebih kuat dari NPH kontralateral dibanding ipsilateral. Oliva inferior memproyeksikan serabut inhibisi ke sel Purkinye flokulus kontralateral, yang menghambat nukleus vestibularis ipsilateral, sehingga lesi NPH akan menyebabkan inhibisi vestibular kontralateral, menyerupai lesi nukleus vestibularis kontralateral. ${ }^{7}$

Pedunkulus serebeli inferior terletak di bagian posterior pons kaudal dan medula rostral, di antara tepi bawah ventrikel ke-4 dan radiks saraf glosofaringeus dan vagus. Struktur ini mengandung serabut aferen dan eferen vestibuloserebelum yang berperan dalam integrasi fungsi propioseptif dan vestibular sehingga lesi pada pedunkulus serebeli inferior dapat menunjukkan sindrom vestibular terisolasi.? 


\section{Pons lateral}

Infark pons dapat diklasifikasikan menjadi anteromedial, anterolateral, tegmental, dan bilateral. Infark pons lateral biasanya disebabkan oklusi AICA atau SCA, dan biasanya berhubungan dengan infark serebelum. Infark kecil di area tegmentum di ventral ventrikel ke-4 menyebabkan lateropulsi tubuh. Hal ini kemungkinan karena kerusakan jaras graviseptif asenden melalui tegmentum pontin paramedian. ${ }^{12}$

\section{Serebelum}

Sebelas persen pasien dengan infark serebelum terisolasi menunjukkan klinis vertigo terisolasi serta sebagian besar (96\%) mengalami infark teritori PICA cabang medial, termasuk nodulus. Struktur serebelum kaudal area PICA cabang medial merupakan struktur yang paling sering mengakibatkan vertigo sentral terisolasi dengan kausa vascular. ${ }^{13}$

Lesi pada uvula, nodulus, dan tonsila inferior yang paling sering bertanggung jawab pada munculnya head-shaking nystagmus pada pasien infark PICA unilateral. Hal ini disebabkan gangguan inhibisi uvulonodular unilateral yang melebihi memori kecepatan. Lesi pada uvulonodular juga akan mengganggu kendali terhadap orientasi spasial dari refleks vestibulookular dan akan memunculkan nistagmus downbeat. Bagian serebelum yang terlibat pada GEN meliputi piramid, uvula, tonsila, lobus biventer dan lobus semilunar inferior. Flokulus diketahui mempunyai peran penting dalam jaringan integrasi neuron untuk mempertahankan gaze. Infark flokulus terisolasi dapat menyebabkan vertigo akut serta kelainan vestibular yang ditandai dengan peningkatan refleks vestibulookular horizontal pada stimulasi frekuensi rendah dan menurun dengan stimulasi frekuensi lebih tinggi. ${ }^{13}$ Tonsila serebeli berperan penting dalam kontrol smooth-pursuit. ${ }^{12}$

\section{Karakteristik Klinis}

Dilaporkan bahwa dizziness lebih umum ditemukan pada pasien stroke dibandingkan vertigo (18\% vs 5\%). Vertigo didefinisikan sebagai ilusi gerak (rotasional atau linear) atau perubahan orientasi vertikal, sedangkan istilah dizziness dipakai untuk menggambarkan sensasi ketidakseimbangan tanpa disertai ilusi gerak. ${ }^{6}$ Enam puluh persen pasien infark serebelum dengan gejala dizziness/vertigo terisolasi mengeluhkan gangguan gait (satu orang pasien tidak dapat melakukan tandem, dua orang pasien menunjukkan gait ataksia, tetapi masih dapat berjalan tanpa bantuan), 40\% melaporkan nyeri kepala, $40 \%$ mengalami tinitus. ${ }^{5}$

Peneliti lain melaporkan bahwa 24 pasien dengan pseudo neuritis vestibular diakibatkan oleh infark serebelum teritori PICA cabang medial, pada pemeriksaan fungsi vestibular dan keseimbangan didapatkan head thrust normal pada semua pasien tersebut, serta $62,5 \%$ ditemukan nistagmus spontan. Sementara itu, dari pemeriksaan GEN ditemukan 54\% merupakan direction-changed bidirectional GEN, 17\% direction-fixed unidirectional GEN, sedang sisanya GEN ke sisi lesi. Pada ke-24 pasien tersebut tidak ditemukan canal paresis dari tes kalori. Postural instability didapatkan pada semua pasien, sebagian besar jatuh ke sisi lesi (71\%), sementara sisanya jatuh ke sisi yang sehat. ${ }^{7}$

Pada pasien dengan infark teritori AICA yang ditandai klinis awal menyerupai labirintitis, semuanya menunjukkan gangguan pendengaran yang dikonfirmasi dengan audiogram yang menunjukkan adanya tuli sensorineural, serta paresis kanal pada telinga yang mengalami gangguan pendengaran tersebut melalui tes kalori. ${ }^{9-10}$ Defisit neurologis fokal muncul kemudian pada pasien-pasien tersebut. Pada saat ditemukan infark dari MRI, semua pasien telah menunjukkan dismetri dan gait ataksia. Nistagmus pada sebagian besar pasien tersebut adalah bidirectional GEN. ${ }^{9}$

Pseudo labirintitis yang mendahului infark teritori AICA ini dicurigai sebagai infark labirin. Infark labirin ditandai oleh vertigo spontan akut, gangguan pendengaran ( $>24 \mathrm{jam})$, dan nistagmus spontan dengan komponen horizontal dan torsional tanpa gejala neurologis lain, pemeriksaan neurolgis tidak menemukan tanda neurologis fokal lain, MRI tidak menemukan infark akut di otak, tes audiovestibular menunjukkan abnormalitas, dan infark teritori AICA diidentifikasi melalui MRI yang dilakukan dalam interval $<4$ hari MRI awal. ${ }^{9}$

Semua pasien dengan infark medula dorsal terisolasi menunjukkan sindrom vestibular akut terisolasi, tetapi $16,7 \%$ pasien juga disertai keluhan 
tinitus. Sebagian pasien mengalami serangan vertigo dengan durasi 1 menit hingga 6 jam dengan/tanpa tinitus sejak 2 minggu hingga 4 bulan sebelum ditemukan infark. Meskipun saat awal onset tidak didapatkan defisit neurologis fokal seperti sindrom Horner, kelainan saraf kranialis, kelemahan, defisit sensoris, maupun tanda keterlibatan serebelum, tetapi $66,7 \%$ pasien menunjukkan defisit fokal dalam 6 hari onset (median 1 hari, rentang interkuartil 0-2 hari). ${ }^{7}$

Lebih dari separuh pasien infark medula dorsal terisolasi menunjukkan klinis kombinasi vestibulopati perifer dan sentral. Tanda vestibular sentral meliputi direction-changing GEN, HIT negatif, skew deviation, head-shaking nystagmus (HSN) berlawanan arah dengan nistagmus spontan, dan disjunctive torsional nystagmus, sedangkan tanda vestibulopati perifer meliputi nistagmus spontan horizontal-torsional yang memberat ketika tanpa fiksasi visual, HIT positif pada 1 atau 2 arah, dan paresis kanal. $^{7}$

Sindrom vestibular akut ditandai dengan vertigo onset akut, mual/muntah, dan gait tidak seimbang yang berhubungan dengan intoleransi terhadap gerakan kepala dan nistagmus yang berlangsung dalam beberapa hari. Protokol head impulse, nystagmus, and test of skew (HINTS) dirancang untuk membedakan antara penyakit vestibular perifer dan stroke pada pasien SVA. Direction-changing nystagmus merupakan marker lesi sentral, dan tidak ditemukan pada neuritis vestibular, sedangkan nistagmus unidireksional tidak secara eksklusif ditemukan pada lesi vestibular perifer karena juga dapat ditemukan pada lesi teritori AICA. Pasien yang mengalami stroke AICA dan PICA secara simultan dapat menunjukkan horizontal-head impulse test (h-HIT) abnormal unilateral, sehingga h-HIT tidak membantu membedakan lesi sentral dan perifer. ${ }^{14}$

Direction-changing nystagmus memiliki sensitivitas 57\% dan spesifisitas 100\%, sehingga bisa dikatakan bahwa penyebabnya hampir tidak pernah perifer. Head impulse test positif merupakan petanda lesi jaras vestibular perifer sehingga seringkali muncul pada lesi vestibular perifer meskipun juga dapat ditemukan pada lesi sentral dengan gangguan nukleus vestibular. Namun, dapat pula ditemukan pada lesi teritori AICA, sehingga pemeriksaan ini dianggap tidak membantu dalam menyingkirkan diagnosis banding. ${ }^{14}$

Skew deviation yang umum ditemukan pada lesi sentral, dapat pula muncul pada neuritis vestibular, dan dapat juga negatif pada lesi sentral. Oleh karena itu sebaiknya tidak digunakan sebagai petanda tunggal. Munculnya skew deviation dengan cover cross-cover test menunjukkan sensitivitas $54,8 \%$ dan spesifisitas $94,4 \%$. Tes ini tidak dapat membedakan lesi perifer dan sentral meskipun tidak umum ditemukan pada lesi perifer. ${ }^{14}$ Skew deviation pada kasus SVA berkaitan erat dengan adanya lesi batang otak, paling sering stroke iskemik di medula oblongata lateral dan pons lateral. Dilaporkan bahwa ditemukannya salah 1 dari 3 tanda bahaya okulomotor (h-HIT normal atau direction-changed horizontal nystagmus pada eccentric gaze atau skew deviation) lebih sensitif dibandingkan semua tanda neurologis tradisional dalam identifikasi kausa stroke pada SVA. Tanda bahaya tersebut mudah diingat dengan akronim impulse normal, fast-phase alternating, refixation on cover test (INFARCT). Lebih penting lagi adalah hasil pemeriksaan HINTS lebih baik dalam menyingkirkan stroke dibanding hasil MRI DWI yang negatif pada 24-48 jam pertama setelah onset gejala, dengan spesifisitas $(96 \%) .{ }^{15}$

Pemeriksaan HINTS terbukti bermanfaat untuk mengidentifikasi stroke dengan AVS. Sebuah studi juga menyatakan bahwa kombinasi ABCD2 score (usia, tekanan darah, gambaran klinis, durasi, dan diabetes melitus), pemeriksaan neurologis umum, serta evaluasi okulomotor dapat menilai risiko stroke akut pada pasien dengan serangan dizziness akut. ${ }^{16}$ Sementara pada studi lainnya, tidak ditemukan perbedaan bermakna antara $\mathrm{ABCD} 2$ score kelompok SVA transient dengan kausa stroke dengan kelompok SVA transient kausa lain. ${ }^{16}$

Head impulse, nystagmus, and test of skew (HINTS) plus gangguan pendengaran akibat iskemik kohlea atau batang otak merupakan pemeriksaan baru yang diharapkan dapat meningkatkan akurasi diagnosis. Vaskularisasi telinga dalam, fourth-nerve 
complex (kohlea, vestibular inferior dan superior, dan saraf fasialis) di cerebellopontine angle, cochlear nerve root entry, serta nukleus kohlearis pada umumnya berasal dari AICA (80\%), arteri basilaris (15-20\%), dan jarang dari PICA. Pada kasus yang melibatkan AICA dan PICA secara bersama-sama, HIT memiliki sensitivitas $83 \%$ dan spesifisitas $100 \%$, tetapi ketika dinilai secara terpisah, sensitivitas pada kasus PICA $100 \%$, tetapi hanya $30 \%$ pada kasus AICA. Pada pasien AVS, HIT negatif menandakan lesi sentral, tetapi hasil positif tidak menyingkirkan kausa sentral, terutama pada pasien dengan lesi teritori AICA. ${ }^{14}$

Pemeriksaan HINTS plus hearing (atau disingkat HINTS plus) dapat meningkatkan sensitivitas diagnostik untuk kasus stroke yang melibatkan infark telinga dalam, yaitu AVS yang disertai gangguan pendengaran unilateral. Gangguan pendengaran pada stroke dapat melalui beberapa mekanisme, yaitu keterlibatan langsung kohlea, infark nukleus kohlearis atau auditory nerve root entry zone di pons lateral. AICA umumnya mensuplai struktur pontin tersebut. Karena faktor anatomi inilah stroke AICA sering disertai gangguan audiovestibular, serta menyerupai fisiologi gerakan mata neuritis vestibular. Lesi dapat terjadi di telinga dalam, atau yang disebut infark labirin. ${ }^{17}$

\section{Faktor Risiko Kejadian Vaskular}

Semua pasien isolated dizziness/vertigo yang terdiagnosis stroke infark didapatkan minimal satu faktor risiko vaskular. Faktor risiko terbanyak adalah hipertensi (68\%), diikuti dislipidemia (53\%), ${ }^{6}$ dilaporkan juga bahwa DM berhubungan secara bermakna dengan infark serebri (melalui MRI DWI) pada pasien isolated dizziness/vertigo. ${ }^{8}$ Pasien stroke serebelum dengan manifestasi dizziness/vertigo ss terisolasi memiliki rasio LDL/HDL yang lebih tinggi dibanding populasi umum $(3,63 \pm 0,80$ vs $2,43 \pm 0,79)$, $80 \%$ di antaranya merupakan perokok aktif. ${ }^{5}$

Peran Neuroimaging dalam Mendeteksi Stroke Infark dengan Manifestasi Dizziness/Vertigo Terisolasi

Pada keenam penelitian tersebut, semua pasien dilakukan pemeriksaan MRI DWI, kecuali pada stroke hemoragik, ${ }^{6}$ serta pasien dengan kondisi yang tidak stabil untuk dilakukan MRI, menjalani CT scan sebagai gantinya. MRI dilakukan pada 0-4 hari setelah onset, satu penelitian dilakukan MRI evaluasi jika hasilnya normal pada MRI awal. Suatu studi pada 130 pasien stroke teritori anterior, yang dilakukan pemeriksaan CT scan dan MRI dalam 3 jam onset. Lesi dinilai dengan Alberta Stroke Program Early CT Score (ASPECTS), dan dilaporkan bahwa DWI mendeteksi lesi iskemik secara signifikan lebih sering dibanding CT scan di semua regio ASPECTS, kecuali di kaput nukleus kaudatus dan kapsula interna. ${ }^{18}$

Pada pasien infark labirin yang mengawali stroke teritori AICA, ditemukan MRI DWI awal normal pada semua pasien, dan setelah dilakukan MRI evaluasi dalam 4 hari setelah onset gejala, teridentifikasi adanya infark di teritori AICA. ${ }^{9}$ Pemeriksaan MRI kepala dengan DWI sequences dan apparent diffusion coefficient (ADC) maps mampu mendeteksi lesi iskemik beberapa menit setelah onset gejala, dengan sensitivitas $88-100 \%$. Sebagian besar kasus negatif palsu yang dilaporkan akibat lesi berukuran kecil, dibawah resolusi spasial teknis. ${ }^{19}$ Sebagian besar laporan penelitian menunjukkan bahwa teknik imaging DWI dan fluid-attenuated inversion recovery (FLAIR) lebih sensitif untuk mendeteksi lesi iskemik awal dibanding T2-weighted imaging (T2-WI). ${ }^{20}$

\section{KESIMPULAN}

Sebanyak 9-10\% dari pasien dizziness/vertigo terisolasi yang memiliki faktor risiko vaskular, ditemukan lesi infark dari pemeriksaan MRI DWI, teritori PICA adalah yang paling sering terlibat. Stroke iskemik akut tidak dapat disingkirkan hanya berdasar hasil pemeriksaan DWI negatif, dan HINTS plus dapat mengidentifikasi sindrom vestibular akut sentral dengan akurasi yang lebih baik dibanding MRI DWI di awal onset gejala.

\section{DAFTAR PUSTAKA}

1. Murdin L, Hussain K, Agm S. Betahistine for symptoms of vertigo (review). Cochrane Libr. 2016;2016(6):CD010696.

2. Thursina C, Dewati E. Pedoman tata laksana vertigo. Kelompok Studi Neurootologi dan Neurooftalmologi: PERDOSSI; 2017. 
3. Chakor RT, Eklare N. Vertigo in cerebrovascular diseases. Int J Otorhinolaryngol Clin. 2012;4(1):46-53.

4. Savitz SI, Caplan LR, Edlow JA. Pitfalls in the diagnosis of cerebellar infarction. Acad Emerg med. 2007; 14:63-8.

5. Perloff MD, Patel NS, Kase CS, Oza AU, Voetsch B, Romero JR. Cerebellar stroke presenting with isolated dizziness: brain mri in 136 patients. Am J Emerg Med. 2017;35(11):1724-9.

6. Doijiri R, Uno H, Miyashita K, Ihara M, Nagatsuka $\mathrm{K}$. How commonly is stroke found in patients with isolated vertigo or dizziness attack? J Stroke Cerebrovasc Dis. 2016;25(10):2549-52.

7. Lee S, Park S, Park J, Kim JK, Han M, BaeH, dkk. Dorsal medullary infarction. distinct syndrome of isolated central vestibulopathy. Stroke. 2015;46:3081-7.

8. Mosarrezai A, Toghae M, Majed M, Aloosh M. Isolated vertigo and possibility of brain ischemia. Arch Iran Med. 2012;15(8):469-71.

9. Kim JS, Cho K, Lee H. Isolated labyrinthine infarction as a harbinger of anterior inferior cerebellar artery territory infarction with normal diffusion-weighted brain MRI. J Neurol Sci. 2009;278(1-2):82-4.

10. Lee H, Sohn SI, Cho YW, Lee SR, Ahn BH, Park BR, dkk. Cerebellar infarction presenting isolated vertigo. Neurology. 2006;67(7):1178-83.

11. Blumenfeld H. Neuroanatomy through clinical cases. Edisi ke-2. Sunderland: Sinauer Associates, Inc. Publisher; 2010.

12. Choi K, Lee H, Kim J. Ischemic syndromes causing dizziness and vertigo. Edisi ke-1. Dalam: Furman JM, Lempert T, editor. Volume 137. Neuro-Otology: Seoul: Elsevier BV. 2016. h. 317-40.
13. Kim H, Yi H, Lee H. Recent advances in cerebellar ischemic stroke syndromes causing vertigo and hearing loss. Cerebellum. 2015;2015:1-8.

14. Carmona S, Martinez C, Zalazar G, Moro M, Batuecas-Caletrio A, Luis L, dkk. The diagnostic accuracy of truncal ataxia and HINTS as cardinal signs for acute vestibular syndrome. Front Neurol. 2016;7:1-6.

15. Kattah JC, Talkad AV, Wang DZ, Hsieh YH, NewmanToker DE. HINTS to diagnose stroke in acute vestibular syndrome. Three-step bedside oculomotor exam more sensitive than early MRI DWI. Stroke. 2009;40(11):3504-10.

16. Choi JH, Park MG, Choi SY, Park KP, Baik SK, Kim JS, dkk. Acute transient vestibular syndrome. prevalence of stroke and efficacy of bedside evaluation. Stroke. 2017;48:556-62.

17. Newman-Toker DE, Curthoys IS, Halmagyi GM. Diagnosing stroke in acute vertigo: the HINTS family of eye movement tests and the future of the "Eye ECG”. Semin Neurol. 2015;35(5):506-21.

18. Mitomi M, Kimura K, Aoki J, Iguchi Y. Comparison of CT and DWI findings in ischemic stroke patients within 3 hours of onset. J Stroke Cerebrovasc Dis. 2014;23(1):37-42.

19. Homem CA, Fonseca AC, Geraldes R, Melo TP. Brain magnetic resonance with negative diffusion-weighted imaging: does it preclude acute stroke diagnosis? J Stroke Cerebrovasc Dis. 2015;24(9):e251-3.

20. Chang WL, Lai JC, Chen RF, Hu HH, Pan CS. Case report of false-negative diffusion-weighted image of brain magnetic resonance imaging (MRI) in acute ischemic stroke. Am J Case Rep. 2017;18:76-9. 